\title{
CLARA CELLS PROTEIN, PROLACTIN AND TRANSCRIPTION FACTORS OF PROTEIN NF- $\kappa B$ AND c-JUN/AP-1 LEVELS IN RATS INHALED TO STAINLESS STEEL WELDING DUST AND ITS SOLUBLE FORM
}

\section{TADEUSZ HAŁATEK ${ }^{1}$, MAGDALENA STANISŁAWSKA ${ }^{1}$, RADOSŁAW ŚWIERCZ², KATARZYNA DOMERADZKA-GAJDA ${ }^{2}$, RENATA KURAŚ ${ }^{1}$, and WOJCIECH WĄSOWICZ1}

\author{
Nofer Institute of Occupational Medicine, Łódź, Poland \\ ${ }^{1}$ Department of Biological and Environmental Monitoring \\ ${ }^{2}$ Department of Toxicology and Carcinogenesis
}

\begin{abstract}
Objectives: Welding processes that generate fumes containing toxic metals, such as hexavalent chromium $(\mathrm{Cr}(\mathrm{VI}))$, manganese, and nickel (Ni), have been implicated in lung injury, inflammation, and lung tumor promotion in animal models. Bronchiolar epithelium Clara cells/club cells, coordinate these inflammatory responses. Clara cells secretory protein (CC16) with ant-inflammatory role. Material and Methods: The pulmonary toxicity of welding dust (WD) was assessed for Wistar rats exposed to $60 \mathrm{mg} / \mathrm{m}^{3}$ of respirable-size welding dust (mean diameter $1.17 \mu \mathrm{m}$ for 1 and 2 weeks $(6 \mathrm{~h} /$ day, 5 days/week)) or the aerosols of soluble form (SWD) in the nose-only exposure chambers. Additionally the effect of antiinflammatory betaine supplementation was assessed. Clara cells secretory protein, differential cell counts, total protein concentrations and cellular enzyme (lactate dehydrogenase - LDH) activities were determined in bronchoalveolar lavage fluid, and corticosterone and thiobarbituric acid reactive substances (TBARS) and prolactin concentrations were assessed in serum. Histopathology examination of lung, brain, liver, kidney, spleen was done. Additionally slices of brain and lung were exanimated in laser ablation inductively coupled plasma mass spectrometry. Results: Both WD and SWD exposure evoked large bronchiolar infiltration shoved in histopathology examination. In this study, TBARS inversely correlated with a significant decrease of $\mathrm{CC} 16$ concentration that occurred after instillation of both WD and SWD indicating decreased anti-inflammatory potential in the lung. In WD exposed rats prolactin correlated with nuclear factor-kappa B (NF- $\varkappa$ B), LDH, TBARS and serum levels Cr, Ni and inversely with c-Jun. In SWD exposed rats prolactin correlated with CC16 indicated effect of prolactin on the population of epithelial cells. Conclusions: In the current study, deleterious effects of repeated inhalation stainless steel welding dust form on club (Clara) cell secretory protein (CC16) were demonstrated. Clara cells secretory protein relation with prolactin in exposed rats to welding dust were shown and explored whether the NF- $x \mathrm{~B}$ and c-Jun/activator protein 1 related pathway was involved. Int J Occup Med Environ Health 2018;31(5):613-632
\end{abstract}

Key words:

Prolactin, Stainless welding, Clara cells protein, NF- $\varkappa$ B, c-Jun/AP-1, LA-ICP-MS

Funding: this research was supported by National Sciences Center (grant No. 2013/09/B/NZ7/0492 entitled "The effects of different exposure to welding fumes of stainless steel on the expression of transcription factors NF- $\varkappa$ B and AP-1 and selected biomarkers of exposure and effects," grant manager: Prof. Tadeusz Hałatek) and partially supported by Institute of Occupational Medicine in Łódź statutory project No. IMP 9.5 entitled "The application of laser ablation inductively coupled plasma mass spectrometry (LA-ICP-MS) to the bioimaging of trace elements in biological samples," project manager: Prof. Wojciech Wąsowicz.

Received: June 30, 2017. Accepted: November 29, 2017.

Corresponding author: Tadeusz Hałatek, Nofer Institute of Occupational Medicine, Department of Biological and Environmental Monitoring, św. Teresy 8, 91-348 Łódź, Poland (e-mail: halatekt@gmail.com). 


\section{INTRODUCTION}

The welding fumes inhalation caused a major problem in occupational medicine, which has long been studied in detail by toxicologists due to high health risk of cardiovascular, respiratory and neurological effects [1-3]. Welding fumes of stainless steel containing in particular chromium $(\mathrm{Cr}(\mathrm{VI}))$ and nickel (Ni) as possible carcinogens to welders have a high priority for risk assessment. In the toxicological evaluation of the effects of exposure to welding fumes of stainless steels (SS welding) studies by animal/ rats inhalation, intra tracheal implementation of collected welding dust or in vitro studies were performed [4-7]. Cena et al. [8] showed that the samples fraction below $300 \mathrm{~nm}$ of welding stainless fume contained the majority of $\mathrm{Cr}$ and $\mathrm{Ni}$ and manganese $(\mathrm{Mn})$ in the entire welding fumes. Welding fumes of stainless steel contain nanoparticles and multiple manganese species soluble and insoluble potentially neurotoxic [9].

Due to chronic exposure to welding fumes of stainless steels, histopathological studies of rats have shown inflammatory changes leading to fibrosis in lung tissue $[10,11]$. Similar inflammatory changes leading to the development of peribronchiolar, perivascular and alveolar fibrosis, together with interstitial inflammation were observed following administration of metal oxide nanoparticles to mice [12]. The assessment of the effects of exposure to metals contained in welding fumes, out of which a significant proportion of the airborne particulates is present in nanoparticles that require appropriate new techniques such as laser ablation inductively coupled plasma mass spectrometry (LA-ICP-MS). Laser ablation inductively coupled plasma mass spectrometry was used last in the toxicological pathology of nanoparticles as well heavy metals $[13,14]$.

Stainless steels welding fumes had the capacity to create the biologically reactive hydroxyl radical $\left({ }^{*} \mathrm{OH}\right)$, probable through the reduction of $\mathrm{Cr}(\mathrm{VI})$ to $\mathrm{Cr}(\mathrm{V})$ [15]. Reactive oxygen species (ROS) generation effected cell growth, migration, apoptosis, inflammation, and fibrosis. Reactive oxygen species elicit these effects by influencing intracellular signaling events [4]. The carcinogenic effect of $\mathrm{Cr}(\mathrm{VI})$ and $\mathrm{Ni}^{2+}$ and the neuroinflammatory action of $\mathrm{Mn}$ has been associated with activation of mostly redox-sensitive transcription factors, engaging nuclear factor-kappa $\mathrm{B}$ (NF- $\varkappa$ B), activator protein 1 (AP-1) and p53 and further signaling factors [16-20].

The lungs have mechanisms of effective combat against inhaled toxic agents causing inflammation. This specific type of exposure affects the bronchiole-alveolar epithelium as the primary destination, causing lung injury. Multiple cells populations, including the bronchiolar epithelium Clara cells/club cells, manage these inflammatory reaction. Club (Clara) cells non-ciliated epithelial cells are situated in the distal airways or in conducting airways, in humans and rats, respectively. The potential relationship between Clara cells/club cells as lung progenitor and epithelial stem cells and lung cancer stem cell-targeted drug development were emphasized [21,22]. It was discovered that Clara cells secretory protein (CC16) protects against pro-inflammatory effect of phospholipase $\mathrm{A} 2$ and $\mathrm{C}$, likely as an effect of an interplay between $\mathrm{CC} 16$ and phospholipid vesicles and disturb binding of phospholipases to the phospholipids [23,24].

Reactive oxygen species generation is a recognized factor in the mechanism induce respiratory inflammation in the exposure to welding fumes and contribute to the disclosure of lung tumorigenesis but there is a lack of knowledge about its target cell type in lung. In the current study, we have investigated the effects of repeated inhalation SS welding dust particles and its soluble forms on Clara/club cells secretory protein (CC16) in rats and inquired whether NF- $\varkappa$ B and/or c-Jun/AP-1 related pathway were involved in the inflammation that was affected by various factors including calcium influx, oxidative stress and inflammatory cytokines over which the NF- $x \mathrm{~B}$ transcription factor was primarily controlled [25]. Calcium 
$\left(\mathrm{Ca}^{2+}\right)$ disequilibrium, may precipitate endoplasmic reticulum (ER) stress, support to overall excitotoxicity and neuronal lethal effect [26].

Neuroinflammatory effects of manganese in welding fumes may be assayed by prolactin (PRL) which was proposed as a biomarker of the manganese neurotoxic activity [27]. Recently it has been reported that PRL disturbs glutamate excitotoxicity by a renewal of the mitochondrial activity and intracellular calcium homeostasis furthermore an anti-apoptotic action maybe indirectly by the action of NF- $x \mathrm{~B}$ [28].

It seems intriguing to determine the influence of welding fumes on prolactin changes in the differentiation of epithelial cells including Clara cells, which may suggest that PRL contributed in controls the proinflammatory effects of lung epithelial cells. Long et al. [29] suggested that $\mathrm{CC} 16$ protein gene transfer may prevent airway inflammation by suppressing incitement of NF- $\varkappa \mathrm{B}$, which may provide us a new guide in the therapy of airway inflammation.

\section{MATERIAL AND METHODS}

\section{Animals and study design}

Male Wistar rats (6-8 weeks old) were acquired as the breeding stock from the Nofer Institute of Occupational Medicine, Łódź, Poland. The rats were kept under conventional conditions (five animals per cage, $12 \mathrm{~h}$ light-dark cycle, $22-28^{\circ} \mathrm{C}, 60 \pm 10 \%$ relative humidity); during the experiment, tap water and standard rat food pellets (Murigran) were available to the animals ad libitum. Before the start of experiment, the animals were randomly divided into 2 groups. One group of 64 rats was divided into 8 rats for 2 time points. One group of 64 rats was divided into 8 rats for 2 time points: 5 days and 10 days inhalation by a fraction of the suspended inhalable welding dust (WD) at $60 \mathrm{mg} / \mathrm{m}^{3} 6 \mathrm{~h} /$ day. Next, rats were inhaled by the soluble fraction of welding dust (SWD) consisting of $100 \mathrm{mg}$ dissolved WD salts suspended air and air-control and saline control $(5 \times$ diluted $)$ at each time point. The sec- ond group of 64 rats was supplemented by betaine at a dose $250 \mathrm{mg} / \mathrm{kg} /$ day p.o. in all study rats groups of 5 days and 10 days inhalation of WD + betaine, soluble samples of WD + betaine, air-control + betaine ad saline control + betaine were also divided into 8 rats for 2 time points. Eight rats in each group were sacrificed at the end of exposure. The study design was accepted by the Local Ethics Committee in Łódź (Opinion No. 5/ŁB/698/2014, issue date: 2014-02-24).

\section{Inhalation and exposure monitoring}

Inhalation exposure in rats was performed using the TSE Systems Head Nose Only Exposure Units (TSE Systems Bad Homburg, Germany). During exposure, the rats were placed in glass restrainer tubes. Temperature, humidity and airflow in the head nose exposure unit were only monitored during each exposure period (TSE Daco Software). Liquid aerosol was generated by a metering unit equipped with a syringe pump and ultrasonic nebulizer. Welding dusts were collected at workplace from industrial filters, then mechanically sifted through $25 \mu \mathrm{m}$-mesh, allowing the formation of the compacted dust, from which solid particles aerosol was generated by a Budiaman (TSE Systems, 700700 series) generator. The geometric mean diameter \pm geometric standard deviation $(\mathrm{GMD} \pm \mathrm{GSD})$ of the suspended WD was $1.2 \pm 2.5 \mu \mathrm{m}$. The mean values of concentration, total surface area, and volume in the nose-only exposure chambers (NOEC) system were maintained at $7.39 \mathrm{E}+03$ particles $/ \mathrm{cm}^{3}, 2.02 \mathrm{E}+05 \mu \mathrm{m}^{2} / \mathrm{cm}^{3}$, and $2.83 \mathrm{E}+05 \mu \mathrm{m}^{3} / \mathrm{cm}^{3}$, respectively.

The soluble fraction (SWD) consists of $100 \mathrm{mg}$ of dissolved salts of welding dust (showing a 10\% solubility in water and suspended in air. Real-time aerosol monitoring continued during inhalation exposure (SpectroPan, TSE Systems), air samples collected in the chamber were filtered on cellulose nitrate filter (Sartorius $0.8 \mu \mathrm{m}$ pore size) and further analyses were done by means of spectrometric techniques. 
The procedure with animals in the control (air and diluted saline), and exposed groups were carried out in the same way. The animal was removed from the breeding cage and placed in a glass tube (restrainer), in which one of its ends was similar in its shape and dimensioned to the anatomical shape and dimensions of rat's head. An aperture was provided at the end of this part of the glass restrainer to enable animal breathing. The other end of the tube through which the rat had been inserted into the restrainer was secured by an elastic cap that prevented the escape of the animal during the inhalation time of over $6 \mathrm{~h}$ daily.

During inhalation, rats were deprived of food and water. The inhalation system was equipped with means to directly monitor the concentration of the chemical, temperature, humidity and air flow into the chamber. The inhalation chamber was provided with a system for a precise quantification of airborne dust particles or mist droplets.

\section{Bronchoalveolar lavage and analysis}

After the last round of the inhalation, the rats were killed under ketamine/xylazine anesthesia by cutting the abdominal aorta and bleeding. For bronchoalveolar lavage the left lobe of a lung was tied and the right lung was lavaged in situ through the trachea twice with cold phosphate-buffered saline (PBS) (2.5 ml/lavage). Both lavage samples were combined and centrifuged for $10 \mathrm{~min}$ at $200 \times \mathrm{g}$.

Concentrations of total protein in bronchoalveolar lavage fluid (BALF) as a marker of vascular and epithelial permeability were measured by the Bedford method on a spectrophotometer (UNICAM UV4-500, England) at $700 \mathrm{~nm}$. Lactate dehydrogenase (LDH) was measured spectrophotometricaly at $340 \mathrm{~nm}$ using a reagent kit purchased by Alpha Diagnostics (Warszawa, Poland) on an Photometer Epoll 20 (Warszawa, Poland).

Standard procedures were employed for total and differential cell numbers evaluation: for valuation of leukocytes, sediment cells from BALF were suspended in PBS treated with Türk reagents and calculated in optical microscopy in a Bürker chamber.

\section{Assay of corticosterone concentration in serum}

Blood samples were gathered from hearts to the centrifuge tubes and then centrifuged at $3500 \mathrm{rpm}$ for $20 \mathrm{~min}$. The level of corticosterone in plasma was assayed by high performance liquid chromatography (HPLC) with betamethasone as an internal standard [30].

\section{Lipid peroxidation}

Serum levels of thiobarbituric acid reactive substances (TBARS) were estimated by application of a spectrofluorometric method with butanol as an extraction agent for TBA-reactive compounds [31]. The quantity of fluorescence of butanol layer was evaluated with the Perkin Elmer Luminescence Spectrometer LS50B (Norwalk, CT, USA). Intra-assay variation $(\mathrm{CV})$ was $3.6 \%(\mathrm{~N}=8)$.

\section{Assay of metals in serum}

Serum samples were collected from the exposed and controls animals. Serum samples were preserved at freezer $\left(-20^{\circ} \mathrm{C}\right)$ in Eppendorf tubes. Before the analysis serum samples were diluted tenfold with $1 \%$ nitric acid $\left(\mathrm{HNO}_{3}\right)$ for the chromium, manganese, nickel measurements. NEXion 320D ICP-MS (Perkin Elmer, SCIEX, USA) was used for the purpose of the trace elements analysis in rats serum. The laboratory efficiently participated in the external quality program carried out by the Institute of Occupational Social and Environmental Medicine of the University of Erlangen, Nuremberg (G-EQUAS).

\section{Assay of brain samples by LA-ICP-MS}

The preparatory procedure of brain samples was followed by fixation in $10 \%$ neutral buffered formalin solution, then embedded in paraffin and cross section at $16 \mu \mathrm{m}$. An Applied Spectra, Inc. (ASI, Fremont, CA) J200 Laser Ablation (LA) instrument equipped with a Nd:YAG $266 \mathrm{~nm}$ 
nanosecond laser was used in combination with a Nexion 320X ICP-MS. Each brain section was sampled in the parallel line mode, with line scan spacing of $0.07 \mathrm{~mm}$, and the sample stage was translated at $0.1 \mathrm{~mm} / \mathrm{s}$. The area ablated not excided $14 \mathrm{~mm}$ in width and $4 \mathrm{~mm}$ in height. Isotopes ${ }^{12} \mathrm{C},{ }^{31} \mathrm{P},{ }^{34} \mathrm{~S}$, and ${ }^{55} \mathrm{Mn}$ were measured using a dwell time of $8 \mathrm{~ms}$ in the peak hopping mode. All LA-ICP-MS data was analyzed and converted into 2D elemental images using Applied Spectra, Inc.'s Data Analysis Software.

\section{Biochemical study}

Enzymatic-immunoassay (ELISA) examination

The analysis of rat Clara cell protein (CC16) was carried out in non-concentrated BALF by enzymatic-immunoassay Rat Clara Cell Protein (CC16) ELISA Kit (CUSABIO BIOTECH CO., LTD, distributed by Biomedica Medizin product Gmbh \& Co KG, Vienna, Austria).

In serum the level of prolactin (PRL) was measured by the Rat Prolactin R ELISA Kit (Sigma-Aldrich Co. LLC, Sait Louis, MO, USA). For detection of active transcription factors proteins in serum we used $\mathrm{LSBio}^{\mathrm{TM}}$ Mouse/ Human/Rat JUN DNA Binding ELISA Kit, (LifeSpan BioSciences, Inc., Seatle, WA, USA) and rat nuclear factor NF- $x$ B p105 subunit ELISA Kit (WuHAN EIAAB Science Co., LTD, Wuhan, China). All enzymatic-immunoassays were performed on a Bio-Rad Microplate Reader Model 550 with Bio-Rad software (Hercules, CA, USA).

\section{Histological examination}

The organs lungs, brain, liver, spleen, nose and kidneys taken for testing were fixed in $10 \%$ phosphate buffered formalin, processed for immersion in paraffin, sectioned and stained with hematoxylin and eosin ( $\mathrm{H} \& \mathrm{E})$ and by Van Gieson's method.

\section{Data analysis}

Statistical estimation of the outcome was carried out using a parametric two-way ANOVA (groups $\times$ measurements).
In the evaluation of significant interaction, differences between groups within successive measurements and between measurements within groups were estimated using one-way ANOVA and Tukey's test.

\section{RESULTS}

Characteristics and the analysis of welding dust particles complemented to characteristics and the analysis of welding dust particles in the nose-only exposure chamber were presented previously in first part of study [32]. It was briefly shown that WD size distribution in the nose-only exposure chamber (NOEC) system was narrower than that of WD in welding-room atmosphere. The concentrations of the generated WD were also kept constant and uniform throughout the exposure period. The geometric mean diameter of the suspended WD was $1.17 \mu \mathrm{m}$. Chromium represents 11\%, Ni 3.7\%, Mn 1.2\%, Fe 51.9\% of total welding fume elements. Mean concentration of total dust measured over the experiment was $51.5 \mathrm{mg} / \mathrm{m}^{3}$. It was found that $10 \%$ of total welding dust sample was dissolved in pure water at $20^{\circ} \mathrm{C}$. Metals forming part of the particulate dust welding fumes, as inhaled into the lungs, and the soluble portion SWD have different dynamics entering from the lungs into the serum. The Figure 1 presents chromium and nickel levels in serum of rats exposed, concentration of both metals is higher after inhalation of particles WD. After 2 weeks the effects were more evident and for nickel levels significantly higher than after 1 week of exposure and that fact suggests depositing of particles in lung and thereafter solubility. The Figure 2 showed that manganese levels in serum welding dust (WD) in exposed rats didn't differ from control (air) and soluble dust (SWD), however after one week of exposure to sodium chloride $(\mathrm{NaCl})$ solution in control $\mathrm{NaCl}$ rats higher levels of $\mathrm{Mn}$ were observed. Levels of copper $(\mathrm{Cu})$ and zinc $(\mathrm{Zn})$ in serum shown in the Figure 3 don't differ between exposed and both controls groups except for high $\mathrm{Zn}$ level after one week of inhalation of $\mathrm{NaCl}$ in the case of the control group, however 


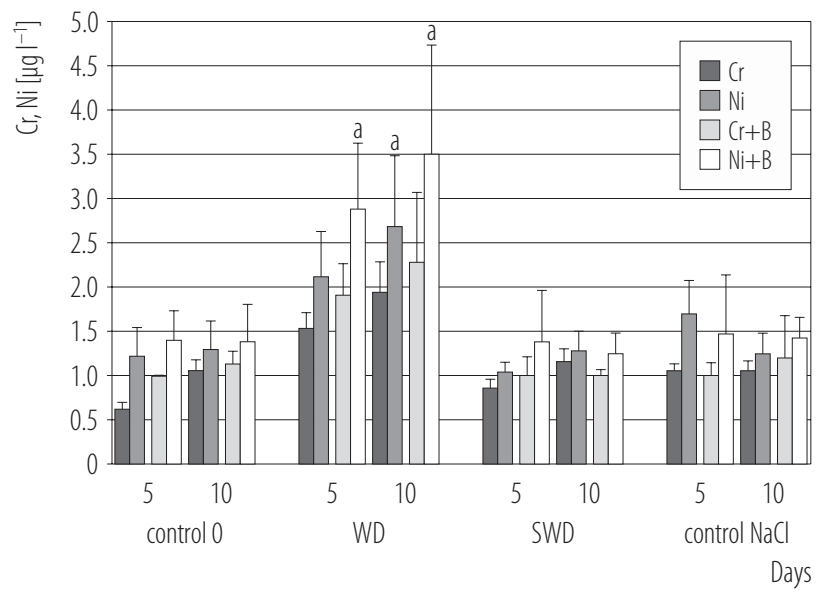

${ }^{\text {a }} \mathrm{p}<0.05$ compared to control 0 .

WD - welding dust; SWD - soluble welding dust; $\mathrm{NaCl}$ - sodium chloride.

Fig. 1. Chromium (Cr) and nickel (Ni) concentration after 5 and 10 days of inhalation (not supplemented or supplemented by betaine (B)) in serum of rats

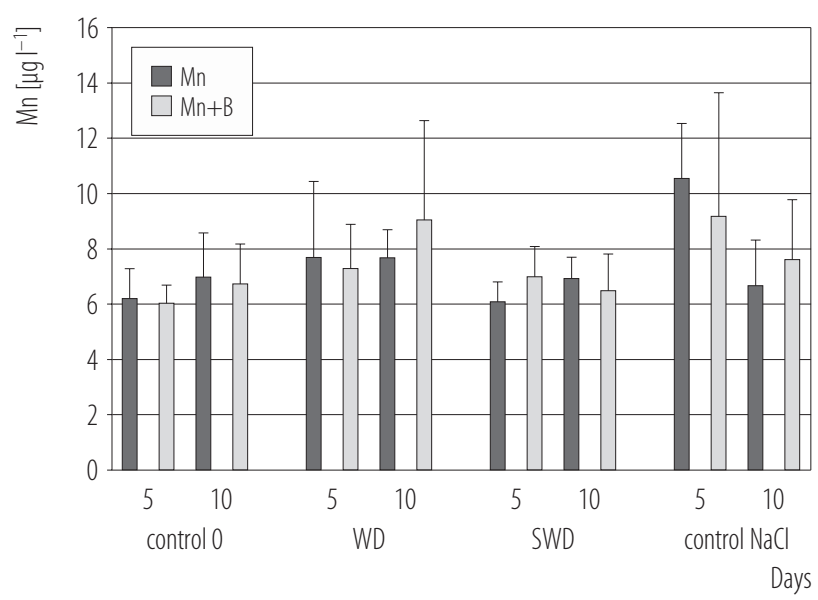

Abbreviations as in Figure 1.

Fig. 2. Manganese $(\mathrm{Mn})$ concentration in serum of rats

slightly not significant statistically lowering levels of $\mathrm{Zn}$ were observed in all betaine supplemented rats.

The morphological studies of lung tissues after 5 days of inhalation WD showed (Photo 1b) macrophages laden with dust and alveolus wall rupturing and developing alveolar emphysema. Large bronchial infiltration, alveolus wall rupturing and alveolar emphysema after 10 days SWD were

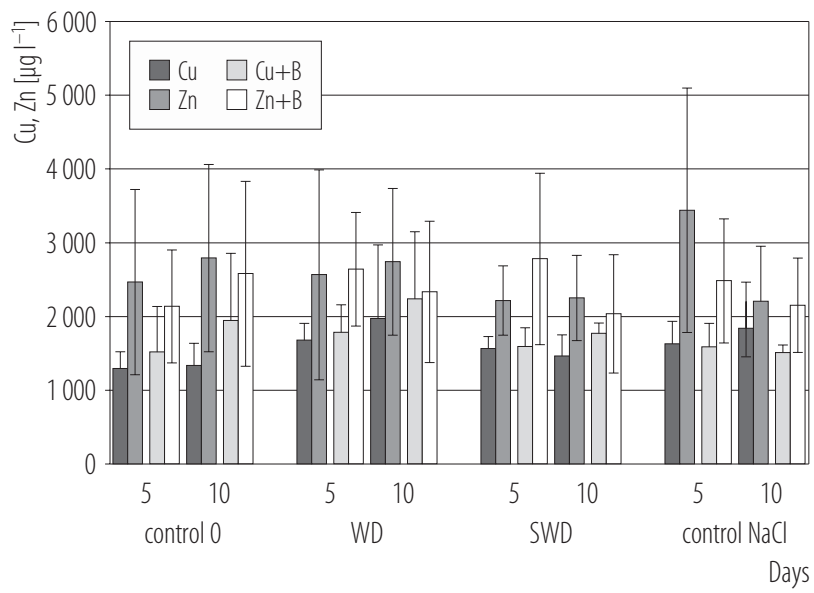

Abbreviations as in Figure 1.

Fig. 3. Copper $(\mathrm{Cu})$ and zinc $(\mathrm{Zn})$ concentration in serum of rats

shown (Photo 1d). Five days after inhalation, WD large bronchiolar inflammatory infiltration was observed and consisted of more than 100 layers of cells (Photo 2a). Betaine supplementation works to diminish the sharpness of these changes. After 10 days of inhalation WD supplemented with betaine (WD + betaine) infiltration around bronchi was less manifested with 20-40 layers of cells (Photo 2b). Histopatological nose examination with throbosis and lymphoid infiltration after 10 days resulted in WD + betaine (Photo 2d).

The Photo 3 presented Mn concentration analysis in brain samples of rats after 5 days of inhalation of LA-ICP-MS. The Figure 4 showed decreasing Clara cells levels in BALF of rats exposed to welding dust WD and soluble fraction SWD and control $\mathrm{NaCl}$ group. Morphological lung deterioration was correlated with a significant decrease of CC16 concentration that occurred immediately after instillation of welding dust samples, indicating decreased anti-inflammatory potential in the lung.

The Figure 5 showed decreasing level of prolactin (PRL) concentration after inhalation by both study welding fraction WD and SWD.

The Figure 6 showed levels of protein NF- $x$ B after inhalation by SS welding fraction. Increased serum concen- 

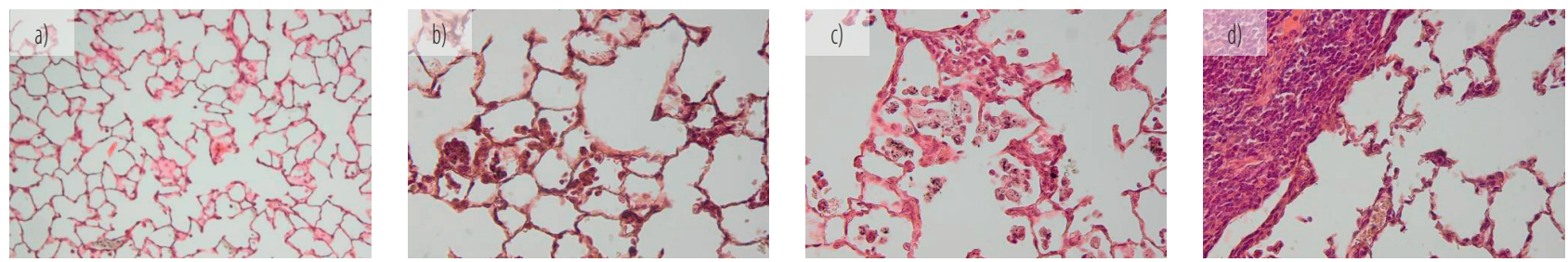

Photo 1. a) Lung control, 200x; b) lung welding dust (WD) 5 days, macrophages laden with dust, alveolus wall rapturing, developing alveolar emphysema, 400x; c) lung $\mathrm{WD}+\mathrm{B}$ (betaine) 10 days, number of macrophages in alveolar lumen, alveolus wall rapturing, 400x; d) lung SWD (soluble welding dust) 10 days, large bronchial infiltration, alveolus wall rapturing, alveolar emphysema, $400 \times$
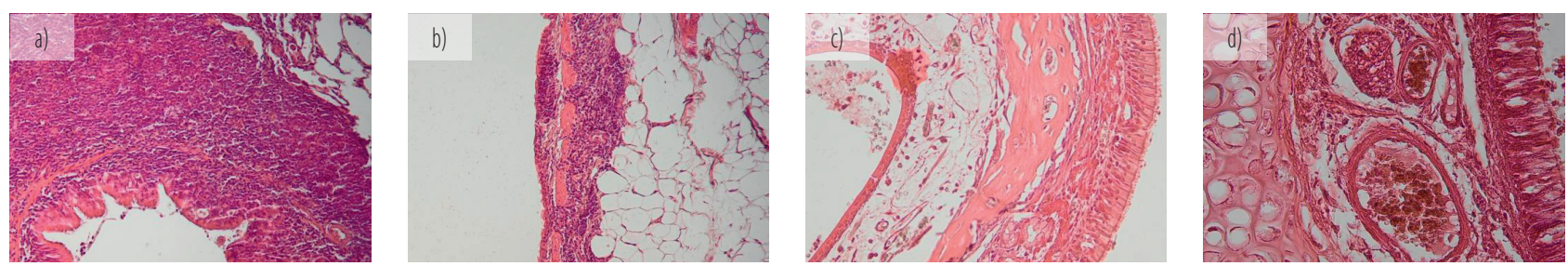

Photo 2. a) Lung welding dust (WD) 5 days, large bronchial inflammatory infiltration, 200x; b) lung WD+B (betaine) 10 days, infiltration around the bronchi, 200X; c) nose control, 200X; d) nose, WD+B 10 days, thrombosis, lymphoid infiltration, 400X
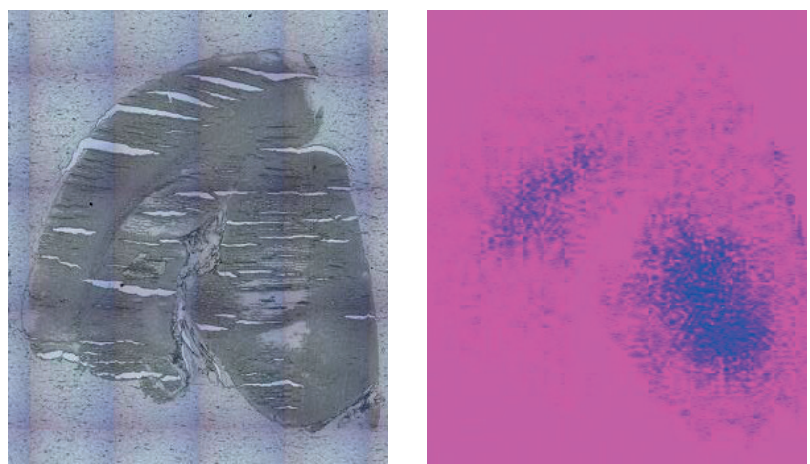

Optical image, Mn distribution in brain tissue,

welding dust (WD) - 5 days.

Photo 3. Manganese (Mn) concentration analysis in brain samples of rats after welding dust (WD) inhalation by laser ablation inductively coupled plasma mass spectrometry (LA-ICP-MS)

tration NF- $\varkappa$ B statistically significant was observed after WD particles inhalation. High level of NF- $\varkappa$ B protein was noted also in $\mathrm{NaCl}$ group.

The Figure 7 showed serum protein levels of transcription factors c-JUN predominantly in WD exposed rats in both 5 days and 10 days exposure group.

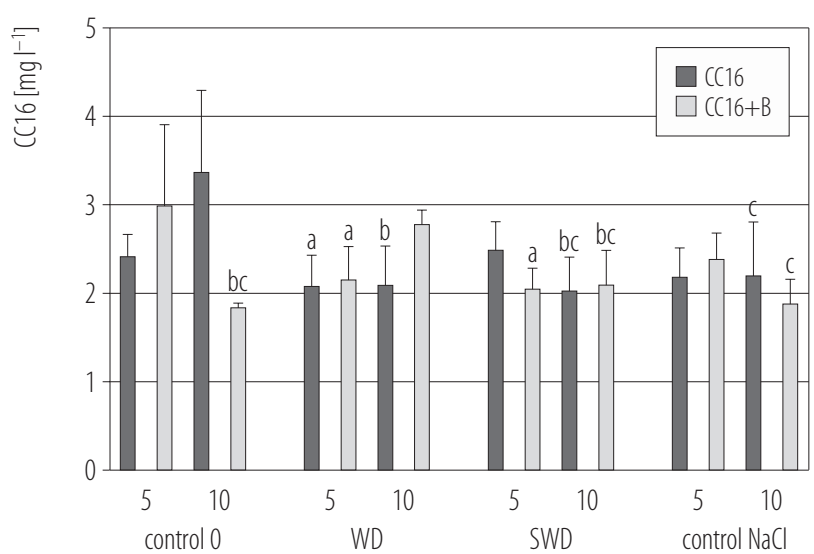

Days

Abbreviations as in Figure 1.

${ }^{a} \mathrm{p}<0.05$ compared to control 0 .

${ }^{\mathrm{b}} \mathrm{p}<0.05$ compared to control $0+\mathrm{B}$.

${ }^{c} \mathrm{p}<0.05$ compared to control $\mathrm{NaCl}$.

Fig. 4. Clara cells secretory protein (CC16) concentration in serum of rats

Chromium exerts a statistically significant influence on rats' weight both in inhalation on WD and SWD (Table 1). Spearman correlation (r) and p-value (p) serum $\mathrm{Cr}$ and Mn levels after administration of soluble salts SWD, cor- 


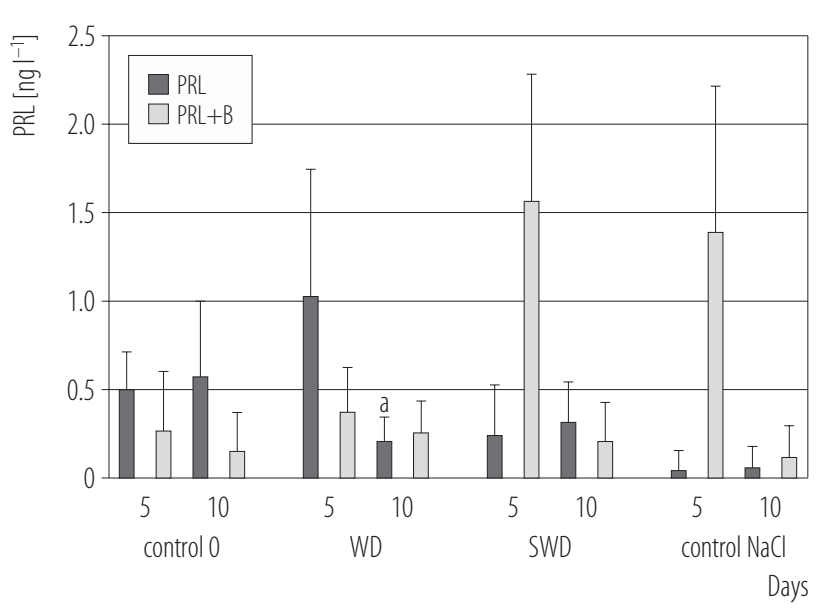

Abbreviations as in Figure 1.

${ }^{\mathrm{a}} \mathrm{p}<0.05$ compared to control 0 .

Fig. 5. Prolactin (PRL) concentration in serum of rats

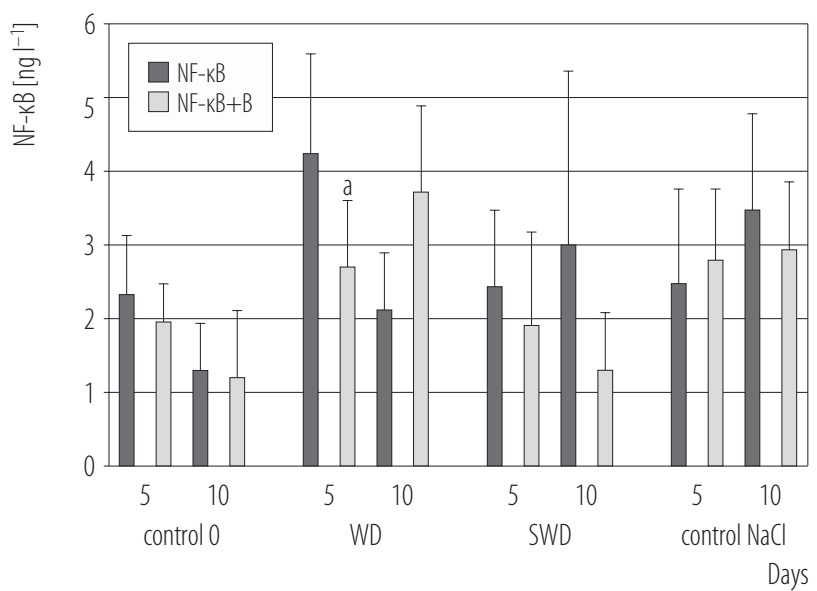

Abbreviations as in Figure 1.

${ }^{a} \mathrm{p}<0.05$ compared to control 0 .

Fig. 6. Nuclear factor-kappa B (NF- $\varkappa \mathrm{B})$ protein concentration in serum of rats

relate closely with lung and brain weight both after 5 days and 10 days. In rat groups after inhalation of dust WD and dust after betaine supplementation (WD+B), serum $\mathrm{Cr}$ levels correlate with organ weight of liver, kidney and brain (Table 1). Leukocytes count correlate closely with $\mathrm{Cr}$ serum levels in SWD rats group after 10 days inhalation (Table 1). Spearman correlation (r) and p-value (p) of exposure indices $\mathrm{Cr}$, Ni and $\mathrm{Mn}$ in serum, body weight, liv-

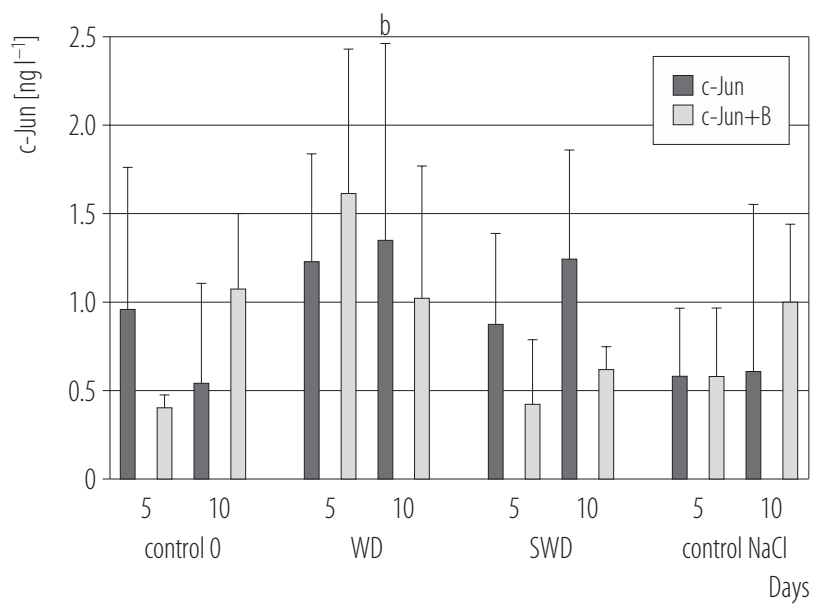

Abbreviations as in Figure 1.

${ }^{\mathrm{b}} \mathrm{p}<0.05$ compared to control $0+\mathrm{B}$.

Fig. 7. c-Jun/activator protein 1 (AP-1) protein concentration in serum of rats

er/100 b.w., kidney/100 b.w., lung/100 b.w., brain/100 b.w., spleen/100 b.w., and leukocytes counts in BALF in both controls (Air) and $\mathrm{NaCl}$ and rats exposed to dust (WD) and soluble form of dust (SWD) (Table 1).

Correlation study showed changes in study markers dependent mostly to nickel concentration in serum (Table 2). Spearman correlation (r) and p-value (p) of exposure indices $\mathrm{Cr}, \mathrm{Ni}$ and $\mathrm{Mn}$ serum levels with concentration of CC16, prolactin and corticosterone, TBARS, LDH and serum protein levels of transcription factors NF- $x \mathrm{~B}$ and c-JUN in controls and rats exposed to dust WD and soluble form of dust SWD. Serum Ni levels after 10 days of dust inhalation correlate with prolactin and CC16 and NF- $\varkappa$ B levels after 5 days of inhalation. Also in the WD-exposed rats the level of Cr correlates with prolactin concentrations in rats group exposed 10 day and inversely with corticosterone, and TBARS level after 5 days. In the WD-exposed rats level of $\mathrm{Mn}$ in serum correlates inversely with CC16 levels r. Protein levels of transcription factors c-Jun correlates with serum $\mathrm{Cr}$, Ni and $\mathrm{Mn}$ concentration in the $(\mathrm{SWD}+\mathrm{B})$ group.

The Table 3 presented Spearman correlation (r) and $\mathrm{p}$-value (p) of CC16, prolactin, corticosterone, $\mathrm{LDH}$, 


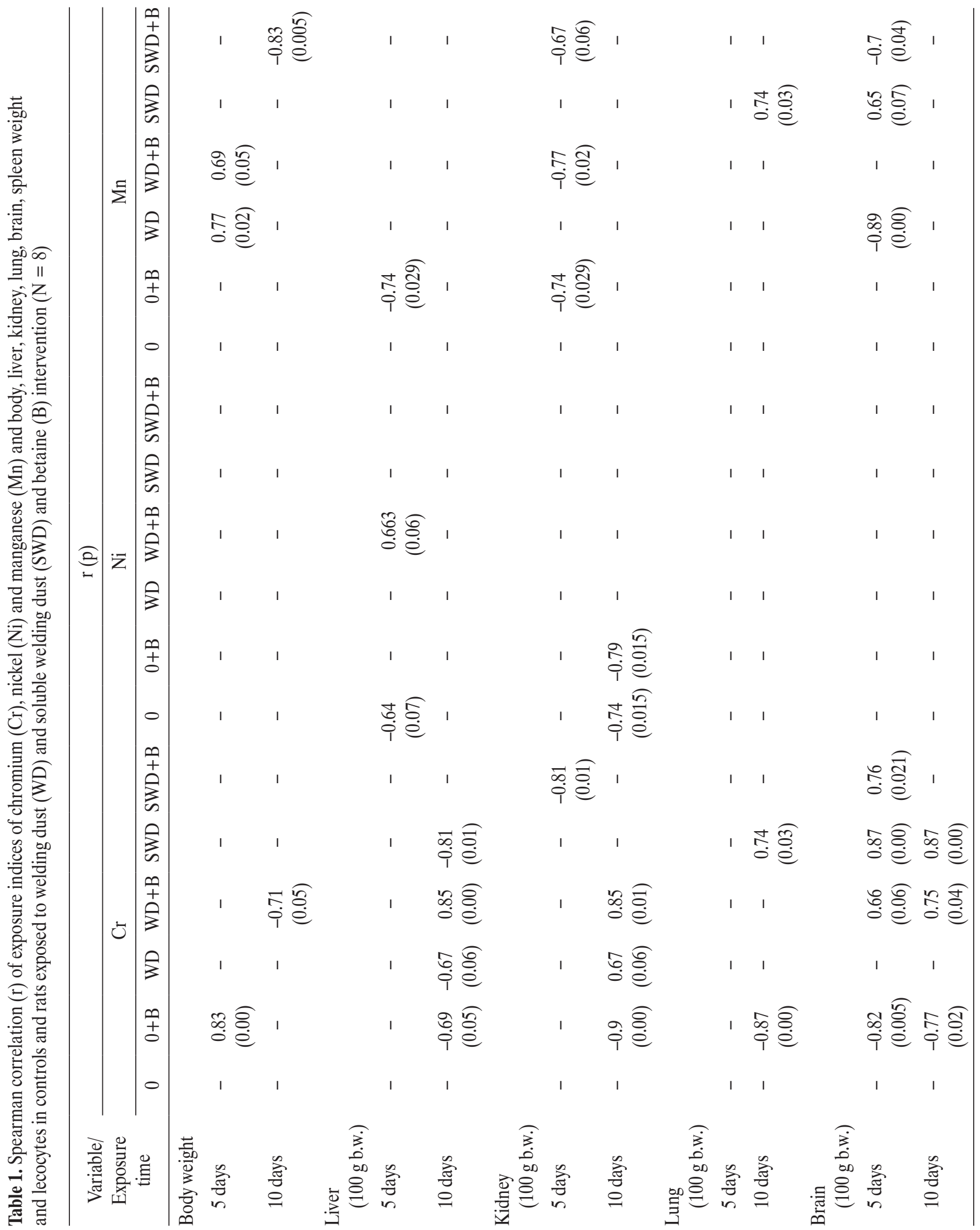




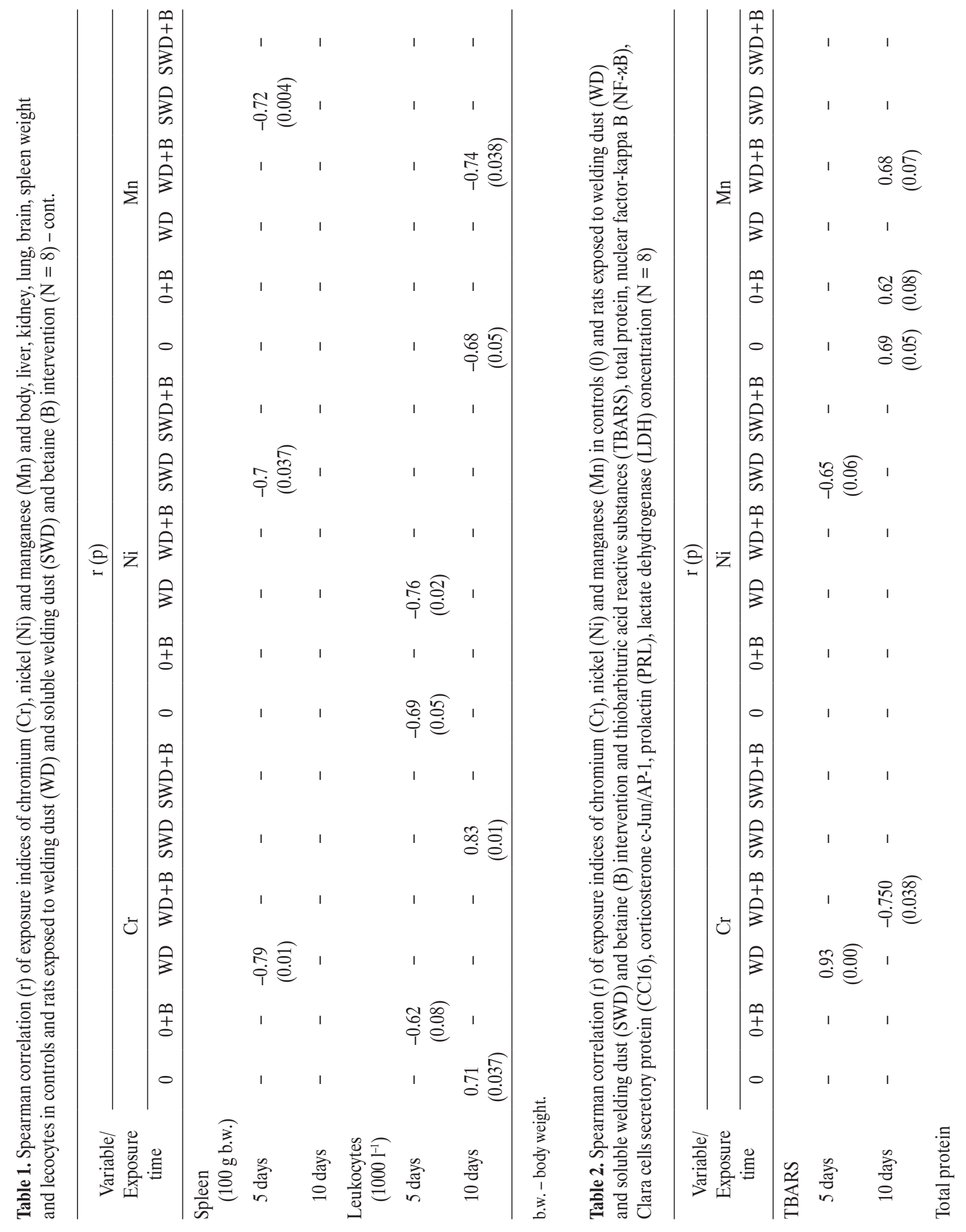




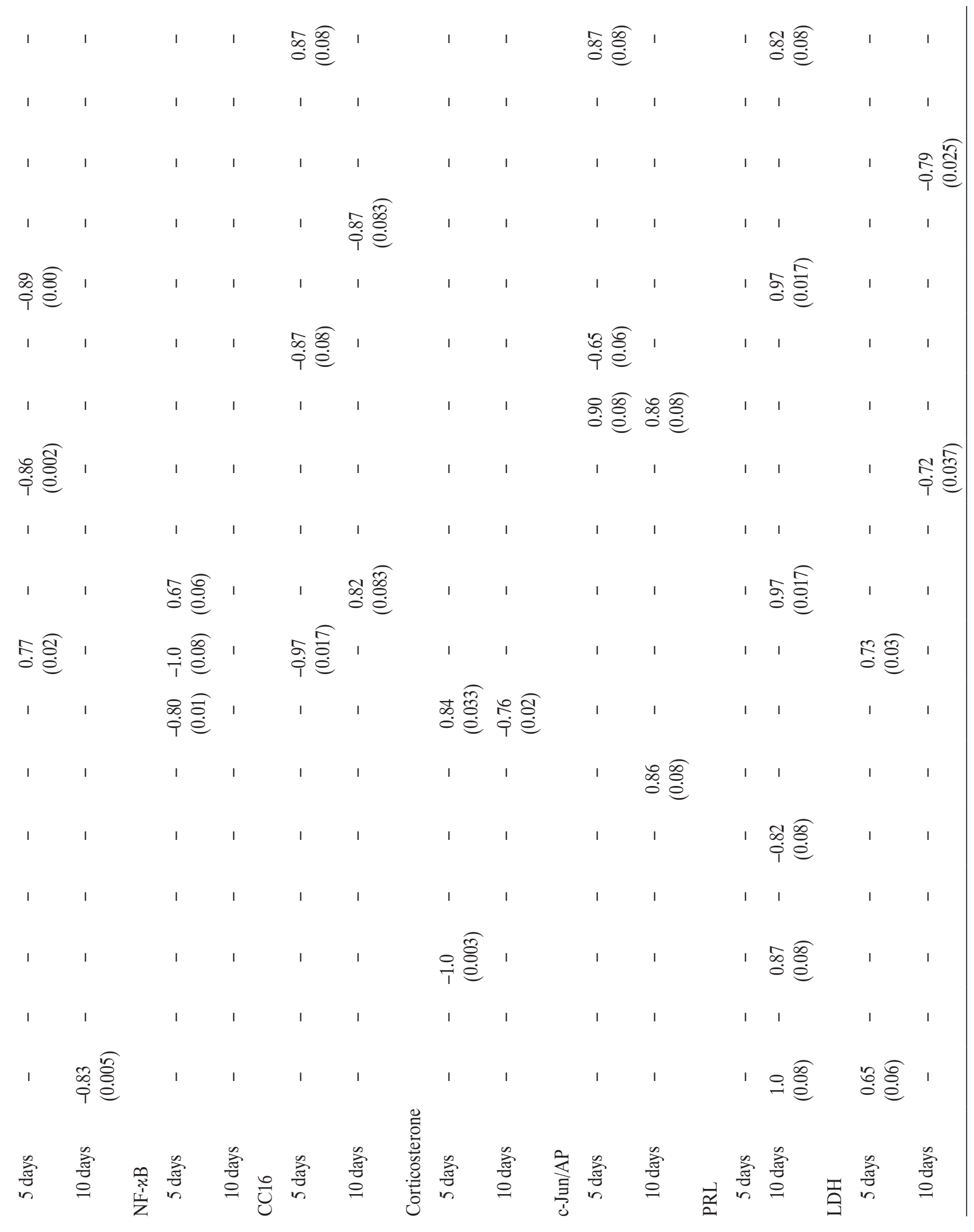




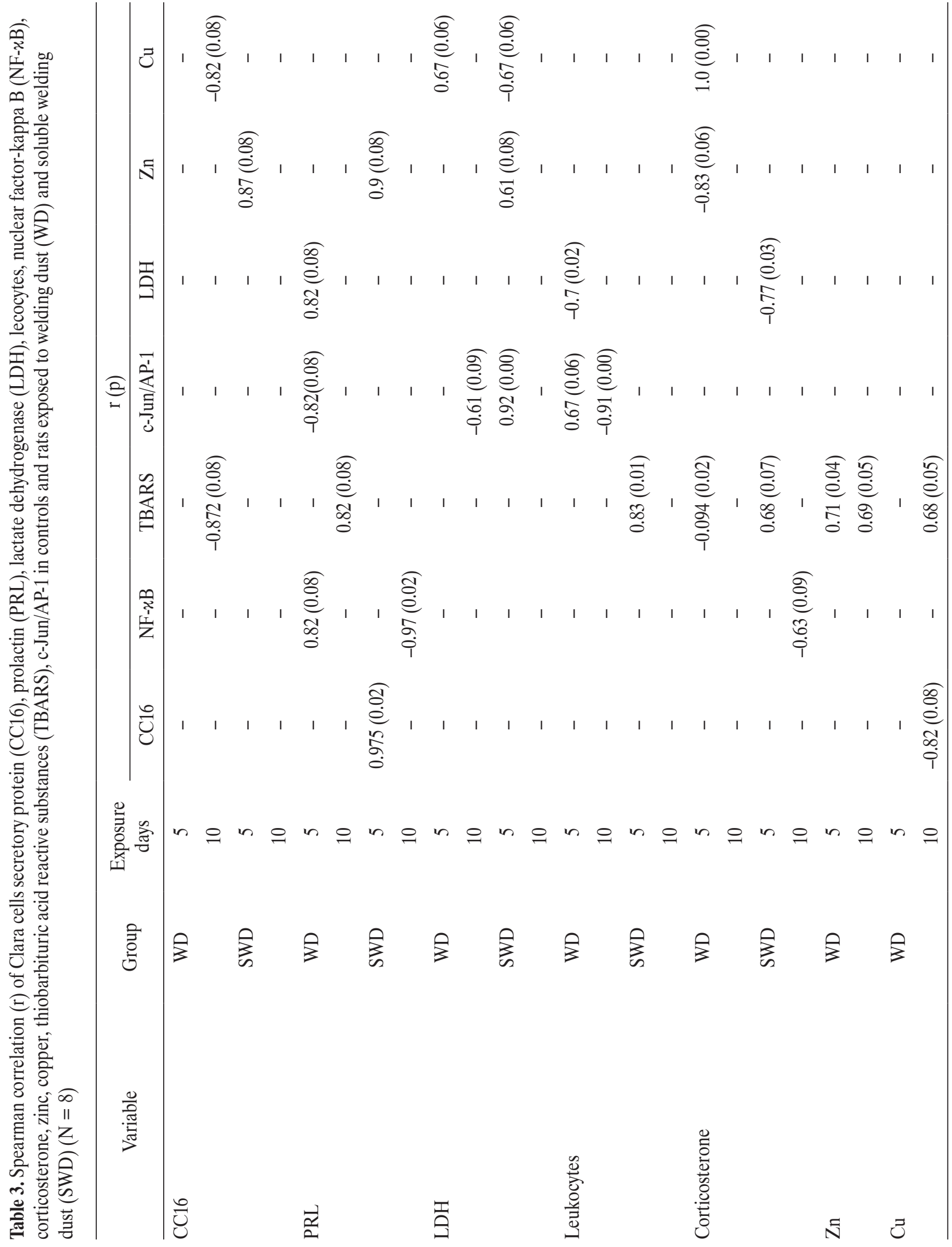


$\mathrm{NF}-x \mathrm{~B}$ and c-Jun, $\mathrm{Zn}, \mathrm{Cu}$ concentration in serum and leukocytes numbers in bells sediments of BALF in rats after 5 days and 10 days of inhalation of WD dust and soluble form of dust (SWD). Clara cells secretory protein closely correlates with prolactin levels after 5 days of SWD inhalation. Clara cells secretory protein correlates inversely with TBARS concentration after 10 days of WD inhalation. Prolactin after 5 days correlates with NF- $x$ B with LDH and inversely with c-Jun and after 10 days with TBARS. Lactate dehydrogenase (LDH) correlates with NF- $\varkappa$ B after 5 days of inhalation with WD. Thiobarbituric acid reactive substances correlates with corticosterone and with $\mathrm{Zn}$ and $\mathrm{Cu}$. In WD rats in 10 days groups $\mathrm{Cu}$ in serum correlated inversely with CC16 and positively with TBARS and with cortycosterone in 5 days group. C-Jun correlated inversely with prolactin after WD after 5 days (Table 3 ).

\section{DISCUSSION}

Welding dust inhalation is known to cause one's health hazard, provokes respiratory inflammation and contributes to the disclosure of lung tumorigenesis but there is a lack of knowledge about its target cell type in lung. In this study, we have investigated the effects of repeated inhalation SS welding dust (WD) and its soluble form (SWD) on club (Clara) cells in the bronchiolar epithelium and Clara cell protein (CC16) in rats and inquired whether the nuclear factor-kappa B (NF- $\varkappa$ B) and or c-Jun/AP-1 related pathways were involved.

Metals present in welding fumes of stainless steels including $\mathrm{Cr}(\mathrm{VI})$ and nickel-induced generation of reactive oxygen species (ROS) $[4,15,33]$. Some study certificate correlation among $\mathrm{Cr}(\mathrm{VI})$-induced generation of ROS and neoplasia process [34-36]. Morphological examination of nasal lung tissue and other renal testes, the liver confirms the inflammatory character of changes in tissues both after administration of WD dust and the soluble fraction of SWD. In lung multi-focal infiltrations in the alveoli, including deposits of dust and crumbling phagocytes, granulocytes and macrophages were seen.

Respiratory exposure biological response is affected by the amount and solubility of the absorbed substance. Inhalation of WD causes slow release of $\mathrm{Cr}$ to serum from the lung deposit (Figure 1). The abundant manganese presence in the brain shown by LA-ICP-MS (Photo 3) was slightly related to the increase in Mn concentration serum (Figure 2). Welding fumes dust in lung epithelium lining fluid (ELF) dissolve in the respiratory milieu and are accessible for absorption [37]. The study of Antonini et al. [15] showed that the welding dust SS sample with majority of $\mathrm{Cr}$ was highly soluble in water and characterized especially explicitly in induction ROS and produce DNA damage, in vivo lung cell apoptosis and lung macrophage cytotoxicity. Inhalation of both WD and SWD causes serum Cr-dependent changes in liver, kidney, lung, spleen and brain weight (Table 1).

After 10 days of inhalation WD highest concentration of $\mathrm{Cr}$ and Ni was achieved by a slow solubility which may have biological consequences. We showed that immunomodulatory effects of inhaled $\mathrm{Cr}(\mathrm{VI})$ upon pulmonary macrophages were increased with low particle solubility [38]. We also noted that rodent species showed variation in carcinogenicity dependent on antioxidant protection and vulnerability to weakly soluble particles [39]. Distinction in the solubility of welding particles affects ROS production and the viability of macrophages. Antonioni et al. [6] found the soluble microarray-based methylation assessment of single sample (MMA-SS) was the most cytotoxic to macrophages, however it must be noted that fraction comprised almost entirely of $\mathrm{Cr}$. Hexavalent chromium penetrating the cell undergoes reduction resulting in oxidative stress and the rise of $\mathrm{Cr}$ ligands. These consequences, jointly with cells proliferation owing to further changes in sequences of DNA and/ or methylation status and cytotoxicity. This in turn leads to destruction of protein and DNA structures and then to tissue changes, irritation, inflammatory and may lead to carcinogenesis [34]. 
Inhalation of both forms of WD and SWD caused increasing levels of the NF- $x$ B and c-Jun/AP-1 (Figure 6) and (Figure 7) signaling factors, respectively. Welding dust inhalation caused statistically significant activation of NF- $x$ B protein.

At the molecular level, the primary adaptive response to welding fume exposure may be the activation of Nrf2 and NF- $\varkappa \mathrm{B}$ signaling pathways in activating the response to ROS and DNA damage.[4]. Meyers' [40] review shows that $\mathrm{Cr}(\mathrm{VI})$ generates irreversible setback of thioredoxin reductase (TrxR) and oxidation of peroxiredoxin (Prx) and thioredoxin (Trx). The proteomics study revealed that Trx1, Trx2 and Prx3 were exceptionally sensitive proteins in impacts $\mathrm{Cr}(\mathrm{VI})$ on cells. Irreversible oxidation of thiol redox protein could be the initiating case that has prevalent association for variety aspects of redox signaling. The signaling assumes shaping many of redox-sensitive transcription factors in this AP-1, NF- $x \mathrm{~B}, \mathrm{Nrf} 2$ and $\mathrm{p} 53$ and the activation of mitogen-activated protein (MAP) kinases (p38 and c-Jun N-terminal kinase (JNK)) and apoptosis signal regulating kinase.

We showed that the transcription factor NF- $\varkappa \mathrm{B} / \mathrm{Nrf}-2$ was strongly manifested in lung tumor tissue and was present in Ni modified human lung bronchial epithelial cells. Nrf2-mediated restrain of apoptosis and dissemination of autophagy made up Ni influenced tumorigenesis [41]. In the mouse model of Parkinson-like disease (PD) NF- $\varkappa$ B/Nrf-2 pathway would be also involved in neuroprotection [21]. In rats the model of inhalation of fumes SS welding was found to prove less neurotoxicity of PD correlated with decreased solubility of manganese located in welding fumes [42]. Inhalation of both WD and SWD causes change in brain and spleen weight related to the concentration of $\mathrm{Mn}$ in serum (Table 1). A statistically significant relationship between serum prolactin and manganese concentrations in rats was found in the betaine supplemented group (Table 2). Betaine supplementation also resulted in high concentration PRL observed in 5 days for the SWD and $\mathrm{NaCl}$ grup (Figure 5).
Betaine promotes the proliferation of mouse spleen lymphocytes that is related to calcium channels [43].

An increase in the intracellular $\mathrm{Ca}^{2+}$ concentration $\left(\left[\mathrm{Ca}^{2+}\right] \mathrm{i}\right)$ is an important signal for PRL secretion [44]. The integrity of the dopaminergic system under the influence of $\mathrm{Mn}$ neurotoxic activity in welding process was shown $[42,45]$. Prolactin was proposed as a biomarker of the manganese neurotoxic activity [27]. Neuro-inflammatory changes in welders have been reported in many studies and reviews [46-49]. Inflammation depends on oxidative stress and inflammatory cytokines which substantially are subjects to control by the transcription factor NF- $\varkappa \mathrm{B}$ which is also influenced by calcium inflow [25]. Palmer [50] showed a close connection between chronic inflammation and activation of NF- $x \mathrm{~B}$ in the cerebral hypothalamus. Nuclear factor-kappa $\mathrm{B}$ elicitation and the enhancing of nitric oxide synthase by ROS was suggested as depicting similar interaction [51].

Chromium also affected NF- $\varkappa$ B/Nrf-2 pathway on the pituitary gland and interacted with prolactin. In the Table 2 correlation between prolactin and $\mathrm{Cr}$ level in rats serum after 10 days of inhalation WD and correlation between prolactin and NF- $x$ B were shown (Table 3 ). We have established that, following in vivo $\mathrm{Cr}(\mathrm{VI})$ application, chromium gathers in the pituitary gland and influences PRL secretion [52,53]. Close correlation between $\mathrm{Cr}$ serum level and corticosterone after 5 days of exposure to WD presented chromium impact to carbohydrate metabolism, hyperglycemia with concomitant increases of insulin and decreases of corticosterone [54]. Chemical stress for 10 days of SDW inhalation resulted in increased level of corticosterone as shown previously in the first part of that study [23]. Corticosterone inversely correlated with the level of NF- $x \mathrm{~B}$ protein (Table 3). At that time SWD inhalation NF- $x$ B inversely correlated with PRL serum levels (Table 3).

These results have confirmed that the adrenal response exacerbate alveolar damage is probably affected by the disability of NF- $\varkappa$ B function engaged in cell resistance. 
Elevation of corticosterone with concomitant decreasing of NF- $\varkappa \mathrm{B}$ was noted as a result of stress condition and increasing of corticosterone with decreasing PRL $[55,56]$. In that study supplementation of betaine with antistress, antioxidant property were done [57]. We also found that the hyperoxia study on mice resulted in broad lung cell necrosis and apoptosis, mild inflammatory response, and raised bloodstream concentration of corticosterone and decreasing NF- $\varkappa$ B activity [58].

It was also approved that the corticosterone was involved in hippocampal neuronal sensibility and toxic action in which raised calcium was firmly engaged in excitant neurotoxic processes [59]. The corticosteroid hormones targets $\mathrm{Ca}\left({ }^{2+}\right)$ channels. However, higher $\mathrm{Ca}\left({ }^{2+}\right)$ burden may enhance vulnerability of limbic cells to undesirable effects as epileptic or ischemic episodes [60]. Elevated intracytoplasmic level of $\mathrm{Ca}^{2+}$ related to stimulated intracellular phospholipases may lead to heavily and preferentially impairment of alveolar epithelial cells [61]. Changes in $\mathrm{Ca}$ levels influence PRL, which is shown in male rats as a hormone interpose calcium channel adjust transepithelial calcium transport in the duodenum of animals [62]. Calcium $\mathrm{Ca}^{2+}$ imbalance may precipitate endoplasmic reticulum (ER) stress, support to overall excitotoxicity and neuronal lethal effect [26]. The cellular calcium ions $\left(\mathrm{Ca}^{2+}\right)$ function as further relay for gene transcript adjustment, cell proliferation, migration and lethal end. Collected data has shown that in carcinoma cells cellular $\mathrm{Ca}^{2+}$ homeostasis is modified and the change is engaged in tumor beginning, angiogenesis, advancement and metastasis [63].

He et al. [64] showed that high sodium diet in mice through participation NF- $x \mathrm{~B}$ induced kidney medullary cyclooxygenase-2 expression and simultaneously support PGE2 synthesis in kidney. In the Figure 4 high levels of NF- $x \mathrm{~B}$ protein were shown in control rats exposed to $\mathrm{NaCl}$ aerosol after 5 days and 10 days. Close correlation between NF- $x \mathrm{~B}$ and serum Ni concentration after WD inhalation after 5 days of inhalation was found (Table 2). Activation of NF- $x$ B with increased cyclooxygenase- 2 a crucial enzyme involved in persistent inflammation related to nickel stimulated neoplastic growth was reported [65]. The Figure 5 showed c-Jun activity predominantly in WD-exposed rats. We demonstrated that p65 and c-Jun were 2 main constituents accordingly engaged in NF- $x \mathrm{~B}$ and $\mathrm{AP}-1$ activation. Both NF- $\varkappa$ B and c-Jun/AP-1 pathways participate in cyclooxygenase-2 elicitation in cells in Cr(VI) exposure [66].

Significant decrease of CC16 concentration occurred after inhalation of both WD and S both dust samples, indicating decreased anti-inflammatory potential in the lung in all exposed groups to welding dust fractions and control $\mathrm{NaCl}$ (Photo 3). Bernard et al. [67], who studied CCl6 under conditions of tobacco fume exposure, was the first author to have noted $\mathrm{CCl} 6$ anti-inflammatory potential. Anti-inflammatory potential of $\mathrm{CC} 16$ in rats exposed to various particles has been described [68]. Clara cells secretory protein counteracts the pro-inflammatory effects of phospholipase $\mathrm{A} 2$ and $\mathrm{C}$, that mechanism is associated with the inability of phospholipases to interact with the phospholipid due to the interaction between $\mathrm{CC16}$ and phospholipid follicles [24]. In terminal bronchioles in Clara cells of COX-2 protein was present and was strongly induced $24 \mathrm{~h}$ after vanadium $\mathrm{V}(2) \mathrm{O}(5)$ exposure, so we proposed that inflammatory progression could be delayed by elicitation of PGE(2) by COX-2 [69]. Yoon et al. [70] showed that CC16 suppressed PGE2 synthesis. Inhibition of NF- $x$ B activity in lung cancer cells was involved in anti-proliferative and anti-metastatic effects of Clara cells protein by abolishing COX-2 expression in lung cancer cells [67]. Long et al. [29] showed that Clara cell $10-\mathrm{kDa}$ protein gene transfer restrained NF- $\varkappa \mathrm{B}$ action in respiratory tract epithelial cells. Close correlation between Clara cells protein and PRL $r=0.975, p=0.02$ was found after 5 days' inhalation of SWD (Table 3), which suggested that those proteins preserved distinction of airway epithelial cells. That data supports the reports that PRL could foster stem cell expansion and stimulus generation of cells to differentiation [71]. 
The toxic effect of the salt complex on the components of stainless steel welding smoke causes a disrupted bronchial epithelium, CC16 concentration decreases significantly after SWD statistics as compared to the control. In previous studies in rats after administration of methylcycloopentadienyl manganese tricarbonyl (MMT) the time course of pulmonary damage and repair processes with the proliferation of Clara cells were seen $48 \mathrm{~h}$ after (MMT) intraperitoneal (i.p.) injection, which was evidenced by the presence of mitotic-phase cells and cells incorporating BrdU into their DNA [72]. The function of the goblet/Clara cell as lung epithelial stem and progenitor cells in the renovation of the bronchiolar epithelium in the mammals was well defined in some investigations [22,23].

Prolactin is described as a final diversification factor for mammillary epithelial cells and messenger in breast neoplasm cells growth and survival.

In the study conducted by Yu-Lee et al. [73] it was demonstrated that the T-cell proliferative response occurred through the gene induced by the PRL - transcription factor-1 interferon regulating factor (IRF-1), which was also influenced by the NF- $x$ B pathway. Prolactin running down the expression of inducible nitric oxide (NO) synthase leading to a reduction in the formation of nitric oxide (NO) in endothelial cells [74]. One of the essential activity of PRL is induction and maintenance in differentiating mammary epithelial cells, which may affect the impairment of cancer progression [75]. Calcium $\mathrm{Ca}^{2+}$ disequilibrium influenced activity of NF- $x \mathrm{~B}$ factors and PRL may be one of the effects of welding fumes intoxication.

\section{CONCLUSIONS}

In this study, deleterious effects of repeated inhalation SS welding dust particles (WD) and soluble forms (SWD) on Clara cell protein (CC16) were demonstrated. Clara cells secretory protein relation with prolactin (PRL) in rats exposed to welding dust were shown and examined if any NF- $x$ B and c-Jun/AP-1 related pathways were involved.

\section{ACKNOWLEDGMENTS}

The skillful works of Alina Knapik-Dąbrowicz, M.D. for the morphology study and Mrs. Barbara Kołodziejczyk for biochemical analysis are highly appreciated.

\section{REFERENCES}

1. Antonini JM. Health effects of welding. Crit Rev Toxicol. 2003;33(1):61-103, https://doi.org/10.1080/713611032.

2. Li H, Hedmer M, Kåredal M, Björk J, Stockfelt L, Tinnerberg $\mathrm{H}$, et al. A cross-sectional study of the cardiovascular effects of welding fumes. PLoS One. 2015;10(7):e0131648, https://doi.org/10.1371/journal.pone.0131648.

3. Racette BA, Criswell SR, Lundin JI, Hobson A, Seixas N, Kotzbauer PT, et al. Increased risk of parkinsonism associated with welding exposure. Neurotoxicology. 2012;33(5):1356-61, https://doi.org/10.1016/j.neuro.2012.08.011.

4. Krishnaraj J, Kowshik J, Sebastian R, Raghavan SC, Nagini S. Exposure to welding fumes activates DNA damage response and redox-sensitive transcription factor signalling in Sprague-Dawley rats. Toxicol Lett. 2017;274:8-19, https://doi. org/10.1016/j.toxlet.2017.04.001.

5. Erdely A, Antonini JM, Young SH, Kashon ML, Gu JK, Hulderman T, et al. Oxidative stress and reduced responsiveness of challenged circulating leukocytes following pulmonary instillation of metal-rich particulate matter in rats. Part Fibre Toxicol. 2014;11:34, https://doi.org/10.1186/s12989-014-0034-8.

6. Antonini JM, Lawryk NJ, Murthy GG, Brain JD. Effect of welding fume solubility on lung macrophage viability and function in vitro. J Toxicol Environ Health A. 1999;58(6):34363, https://doi.org/10.1080/009841099157205.

7. Leonard SS, Chen BT, Stone SG, Schwegler-Berry D, Kenyon AJ, Frazer D, et al. Comparison of stainless and mild steel welding fumes in generation of reactive oxygen species. Part Fibre Toxicol. 2010;7:32, https://doi.org/10.1186/1743-8977-7-32.

8. Cena LG, Chisholm WP, Keane MJ, Chen BT. A field study on the respiratory deposition of the nano-sized fraction of mild and stainless steel welding fume metals. J Occup Environ Hyg. 2015; 12(10):721-8, https://doi.org/10.1080/15459624.2015.1043055. 
9. Keane M, Stone S, Chen B. Welding fumes from stainless steel gas metal arc processes contain multiple manganese chemical species. J Environ Monit. 2010;12(5):1133-40, https://doi.org/10.1039/b922840c.

10. Antonini JM, Stone S, Roberts JR, Chen B, Schwegler-Berry D, Afshari AA, et al. Effect of short-term stainless steel welding fume inhalation exposure on lung inflammation, injury, and defense responses in rats. Toxicol Appl Pharmacol. 2007;223(3):234-45, https://doi.org/10.1016/j.taap. 2007.06.020.

11. Sung JH, Choi BG, Maeng SH, Kim SJ, Chung YH, Han JH, et al. Recovery from welding-fume-exposure-induced lung fibrosis and pulmonary function changes in sprague dawley rats. Toxicol Sci. 2004;82(2):608-13, https://doi.org/10.1093/ toxsci/kfh289.

12. Présumé M, Simon-Deckers A, Tomkiewicz-Raulet C, Le Grand B, Tran Van Nhieu J, Beaune G, et al. Exposure to metal oxide nanoparticles administered at occupationally relevant doses induces pulmonary effects in mice. Nanotoxicology. 2016;10(10):1535-44, https://doi.org/10.1080/174353 90.2016.1242797.

13. Hsiao IL, Bierkandt FS, Reichardt P, Luch A, Huang YJ, Jakubowski N, et al. Quantification and visualization of cellular uptake of $\mathrm{TiO} 2$ and $\mathrm{Ag}$ nanoparticles: Comparison of different ICP-MS techniques. J Nanobiotechnology. 2016;14(1):50, https://doi.org/10.1186/s12951-016-0203-z.

14. Yamagishi Y, Furukawa S, Tanaka A, Kobayashi Y, Sugiyama A. Histopathological localization of cadmium in rat placenta by LA-ICP-MS analysis. J Toxicol Pathol. 2016;29(4):279-83, https://doi.org/10.1293/tox.2016-0022.

15. Antonini JM, Leonard SS, Roberts JR, Solano-Lopez C, Young SH, Shi X, et al. Effect of stainless steel manual metal arc welding fume on free radical production, DNA damage, and apoptosis induction. Mol Cell Biochem. 2005;279(12):17-23, https://doi.org/10.1007/s11010-005-8211-6.

16. Moreno JA, Streifel KM, Sullivan KA, Hanneman WH, Tjalkens RB. Manganese-induced NF- $x \mathrm{~B}$ activation and nitrosative stress is decreased by estrogen in juvenile mice.
Toxicol Sci. 2011;122(1):121-33, https://doi.org/10.1093/toxsci/kfr091.

17. Valko M, Morris H, Cronin MT. Metals, toxicity and oxidative stress. Curr Med Chem. 2005;12(10):1161-208, https:// doi.org/10.2174/0929867053764635.

18. McNeilly JD, Jiménez LA, Clay MF, MacNee W, Howe A, Heal MR, et al. Soluble transition metals in welding fumes cause inflammation via activation of NF- $\varkappa$ B and AP-1. Toxicol Lett. 2005;158(2):152-7, https://doi.org/10.1016/j.toxlet. 2005.03.005.

19. Zuo Z, Cai T, Li J, Zhang D, Yu Y, Huang C. Hexavalent chromium $\mathrm{Cr}(\mathrm{VI})$ up-regulates COX-2 expression through an NF- $\varkappa$ B/c-Jun/AP-1-dependent pathway. Environ Health Perspect. 2012;120(4):547-53, https://doi.org/10.1289/ehp. 1104179.

20. Campolo M, Casili G, Biundo F, Crupi R, Cordaro M, Cuzzocrea S, et al. The neuroprotective effect of dimethyl fumarate in an MPTP-mouse model of Parkinson's disease: Involvement of reactive oxygen species/nuclear factor- $\varkappa \mathrm{B} /$ nuclear transcription factor related to NF-E2. Antioxid Redox Signal. 2017;27(8):453-71, https://doi.org/10.1089/ ars.2016.6800.

21. Reynolds SD, Malkinson AM. Clara cell: Progenitor for the bronchiolar epithelium. Int J Biochem Cell Biol. 2010;42(1):1-4, https://doi.org/10.1016/j.biocel.2009.09.002.

22. Deng M, Li J, Gan Y, Chen P. [Advances in classification and research methods of lung epithelial stem and progenitor cells]. Zhongguo Fei Ai Za Zhi. 2017;20(2):130-7, https:// doi.org/10.3779/j.issn.1009-3419.2017.02.08. Chinese.

23. Halatek T, Hermans C, Broeckaert F, Wattiez R, Wiedig M, Toubeau G, et al. Quantification of Clara cell protein in rat and mouse biological fluids using a sensitive immunoassay. Eur Respir J. 1998;11(3):726-33.

24. Lesur O, Bernard A, Arsalane K, Lauwerys R, Bégin R, Cantin A, et al. Clara cell protein (CC-16) induces a phospholipase A2-mediated inhibition of fibroblast migration in vitro. Am J Respir Crit Care Med. 1995 Jul;152(1):290-7, https://doi.org/10.1164/ajrccm.152.1.7541278. 
25. Ientile R, Currò M, Caccamo D. Transglutaminase 2 and neuroinflammation. Amino Acids. 2015;47(1):19-26, https:// doi.org/10.1007/s00726-014-1864-2.

26. Dong Y, Kalueff AV, Song C. N-methyl-d-aspartate receptor-mediated calcium overload and endoplasmic reticulum stress are involved in interleukin-1beta-induced neuronal apoptosis in rat hippocampus. J Neuroimmunol. 2017;307:713, https://doi.org/10.1016/j.jneuroim.2017.03.005.

27. Marreilha Dos Santos AP, Lopes Santos M, Batoréu MC, Aschner M. Prolactin is a peripheral marker of manganese neurotoxicity. Brain Res. 2011;1382:282-90, https://doi.org/ 10.1016/j.brainres.2011.01.047.

28. Rivero-Segura NA, Flores-Soto E, García de la Cadena S, Coronado-Mares I, Gomez-Verjan JC, Ferreira DG, et al. Prolactin-induced neuroprotection against glutamate excitotoxicity is mediated by the reduction of $[\mathrm{Ca} 2+]$ i overload and NF- $\varkappa B$ activation. PLoS One. 2017;12(5):e0176910, https://doi.org/10.1371/journal.pone.0176910.

29. Long XB, Hu S, Wang N, Zhen HT, Cui YH, Liu Z. Clara cell $10-\mathrm{kDa}$ protein gene transfection inhibits NF- $\varkappa \mathrm{B}$ activity in airway epithelial cells. PLoS One. 2012;7(4):e35960, https://doi.org/10.1371/journal.pone.0035960.

30. Ling S, Jamali F. Effect of cannulation surgery and restraint stress on the plasma corticosterone concentration in the rat: Application of an improved corticosterone HPLC assay. J Pharm Pharmaceutic Sci. 2003;6:246-51.

31. Wasowicz W, Nève J, Peretz A. Optimized steps in fluorometric determination of thiobarbituric acid-reactive substances in serum: importance of extraction $\mathrm{pH}$ and influence of sample preservation and storage. Clin Chem. 1993;39:2522-6.

32. Halatek T, Stanislawska M, Kaminska I, Cieslak M, Swiercz R, Wasowicz W. The time-dependent health and biochemical effects in rats exposed to stainless steel welding dust and its soluble form. J Environ Sci Health A Tox Hazard Subst Environ Eng. 2017;52(3):265-73, https://doi.org/10.10 80/10934529.2016.1253397.

33. Das KK, Das SN, Dhundasi SA. Nickel, its adverse health effects \& oxidative stress. Indian J Med Res. 2008;128(4):412-25.
34. Yao H, Guo L, Jiang BH, Luo J, Shi X. Oxidative stress and chromium(VI) carcinogenesis. J Environ Pathol Toxicol Oncol. 2008;27(2):77-88, https://doi.org/10.1615/JEnvironPatholToxicolOncol.v27.i2.10.

35. Proctor DM, Suh M, Mittal L, Hirsch S, Valdes Salgado $\mathrm{R}$, Bartlett $\mathrm{C}$, et al. Inhalation cancer risk assessment of hexavalent chromium based on updated mortality for Painesville chromate production workers. J Expo Sci Environ Epidemiol. 2016;26(2):224-31, https://doi.org/10.1038/ jes.2015.77.

36. Zhao L, Song Y, Pu J, Guo J, Wang Y, Chen Z, et al. Effects of repeated $\mathrm{Cr}(\mathrm{VI})$ intratracheal instillation on club (Clara) cells and activation of nuclear factor-kappa B pathway via oxidative stress. Toxicol Lett. 2014;231(1):72-81, https://doi. org/10.1016/j.toxlet.2014.09.011.

37. Berlinger B, Ellingsen DG, Náray M, Záray G, Thomassen Y. A study of the bio-accessibility of welding fumes. J Environ Monit. 2008;10(12):1448-53, https://doi.org/10.1039/ b806631k.

38. Cohen MD, Zelikoff JT, Chen LC, Schlesinger RB. Immunotoxicologic effects of inhaled chromium: Role of particle solubility and co-exposure to ozone. Toxicol Appl Pharmacol. 1998;152(1):30-40, https://doi.org/10.1006/taap.1998.8502.

39. Borm PJ, Schins RP, Albrecht C. Inhaled particles and lung cancer, part B: Paradigms and risk assessment. Int J Cancer. 2004;110(1):3-14, https://doi.org/10.1002/ijc.20064.

40. Myers CR. The effects of chromium(VI) on the thioredoxin system: Implications for redox regulation. Free Radic Biol Med.2012;52(10):2091-107, https://doi.org/10.1016/j.freerad biomed.2012.03.013.

41. Son YO, Pratheeshkumar P, Divya SP, Zhang Z, Shi X. Nuclear factor erythroid 2-related factor 2 enhances carcinogenesis by suppressing apoptosis and promoting autophagy in nickel-transformed cells. J Biol Chem. 2017;292(20):831530, https://doi.org/10.1074/jbc.M116.773986.

42. Sriram K, Lin GX, Jefferson AM, Stone S, Afshari A, Keane MJ, et al. Modifying welding process parameters can reduce the neurotoxic potential of manganese-containing 
welding fumes. Toxicology. 2015;328:168-78, https://doi.org/ 10.1016/j.tox.2014.12.015.

43. Ji NY, Park MY, Kang YH, Lee CI, Kim DG, Yeom YI, et al. Evaluation of annexin II as a potential serum marker for hepatocellular carcinoma using a developed sandwich ELISA method. Int J Mol Med. 2009;24(6):765-71.

44. Bulayeva NN, Wozniak AL, Lash LL, Watson CS. Mechanisms of membrane estrogen receptor-alpha-mediated rapid stimulation of $\mathrm{Ca} 2+$ levels and prolactin release in a pituitary cell line. Am J Physiol Endocrinol Metab. 2005;288(2):E38897, https://doi.org/10.1152/ajpendo.00349.2004.

45. Kim HY, Lee CK, Lee JT, Moon CS, Ha SC, Kang SG, et al. Effects of manganese exposure on dopamine and prolactin production in rat. Neuroreport. 2009;20(1):69-73, https:// doi.org/10.1097/WNR.0b013e328315cd35.

46. McMillan G. Is electric arc welding linked to manganism or Parkinson's disease? Toxicol Rev. 2005;27:237-57, https:// doi.org/10.2165/00139709-200524040-00004.

47. Bowler RM, Roels HA, Nakagawa S, Drezgic M, Diamond E, Park R. Dose-effect relationships between manganese exposure and neurological, neuropsychological and pulmonary function in confined space bridge welders. Occup Environ Med. 2007;64:167-77, https://doi.org/10.1136/ oem.2006.028761.

48. Bowler RM, Gocheva V, Harris M, Ngo L, Abdelouahab N, Wilkinson J. Prospective study on neurotoxic effects in manganese-exposed bridge construction welders. Neurotoxicology. 2011;32:596-605, https://doi.org/10.1016/j.neuro. 2011.06.004.

49. Searles Nielsen S, Checkoway H, Criswell SR, Farin FM, Stapleton PL, Sheppard L. Inducible nitric oxide synthase gene methylation and parkinsonism in manganese-exposed welders. Parkinsonism Relat Disord. 2015;21:355-60, https:// doi.org/10.1016/j.parkreldis.2015.01.007.

50. Palmer C. Molecules in the brain trigger ageing. Nature 2013 May 1, https://doi.org/10.1038/nature.2013.12891.

51. Prabhakaran K, Ghosh D, Chapman GD, Gunasekar PG. Molecular mechanism of manganese exposure-induced dopaminergic toxicity. Brain Res Bull. 2008;76:361-7, https:// doi.org/10.1016/j.brainresbull.2008.03.004.

52. Quinteros FA, Machiavelli LI, Miler EA, Cabilla JP, Duvilanski BH. Mechanisms of chromium (VI)-induced apoptosis in anterior pituitary cells. Toxicology. 2008;249(2-3):10915, https://doi.org/10.1016/j.tox.2008.04.012.

53. Nudler SI, Quinteros FA, Miler EA, Cabilla JP, Ronchetti SA, Duvilanski BH. Chromium VI administration induces oxidative stress in hypothalamus and anterior pituitary gland from male rats. Toxicol Lett. 2009;185(3):187-92, https://doi. org/10.1016/j.toxlet.2009.01.003.

54. Chen WY, Mao FC, Liu CH, Kuan YH, Lai NW, Wu CC, et al. Chromium supplementation improved post-stroke brain infarction and hyperglycemia. Metab Brain Dis. 2016;31(2):289-97, https://doi.org/10.1007/s11011-015-9749-y.

55. Ferreira ZS, Bothorel B, Markus RP, Simonneaux V. Plasma corticosterone elevation inhibits the activation of nuclear factor kappa B (NF- $x$ B) in the Syrian hamster pineal gland. Stress. 2012;15(3):339-47, https://doi.org/10.3109/10253890. 2011.627070.

56. Thellin O, Noel G, Khurana S, Ogle CK, Horseman ND. Stress hormone secretion and gut signal transducer (STAT) proteins after burn injury in rats. Shock. 2001;16(5):393-7, https://doi.org/10.1097/00024382-200116050-00013.

57. Ganesan B, Anandan R, Lakshmanan PT. Studies on the protective effects of betaine against oxidative damage during experimentally induced restraint stress in Wistar albino rats. Cell Stress Chaperones. 2011;16:641-52, https://doi. org/10.1007/s12192-011-0276-4.

58. Barazzone-Argiroffo C, Pagano A, Juge C, Métrailler I, Rochat A, Vesin C, et al. Glucocorticoids aggravate hyperoxiainduced lung injury through decreased nuclear factor- $x \mathrm{~B}$ activity. Am J Physiol Lung Cell Mol Physiol. 2003;284(1): L197-204, https://doi.org/10.1152/ajplung.00239.2002.

59. Eliott EM, Sapolski RM. Corticosterone impairs hippocampal neuronal calcium regulation - Possible mediating mechanisms. Brain Res. 1993;602:84-90, https://doi. org/10.1016/0006-8993(93)90245-I. 
60. Joëls M, Karst H. Corticosteroid effects on calcium signaling in limbic neurons. Cell Calcium. 2012;51(3-4):277-83, https://doi.org/10.1016/j.ceca.2011.11.002.

61. Rice KL, Duane PG, Mielke G, Sinha AA, Niewoehner DE. Calcium ionophores injure alveolar epithelial cells: Relation to phospholipase activity. Am J Physiol. 1990;259:439-50, https://doi.org/10.1152/ajplung.1990.259.6.L439.

62. Dorkkam N, Wongdee K, Suntornsaratoon P, Krishnamra N, Charoenphandhu N. Prolactin stimulates the L-type calcium channel-mediated transepithelial calcium transport in the duodenum of male rats. Biochem Biophys Res Commun. 2013;430(2):711-6, https://doi.org/10.1016/j.bbrc. 2012.11.085.

63. Cui C, Merritt R, Fu L, Pan Z. Targeting calcium signaling in cancer therapy. Acta Pharm Sin B. 2017;7(1):3-17, https:// doi.org/10.1016/j.apsb.2016.11.001.

64. He W, Zhang M, Zhao M, Davis LS, Blackwell TS, Yull F, et al. Increased dietary sodium induces COX2 expression by activating NF- $x \mathrm{~B}$ in renal medullary interstitial cells. Pflugers Arch. 2014;466(2):357-67, https://doi.org/10.1007/ s00424-013-1328-7.

65. Cai T, Li X, Ding J, Luo W, Li J, Huang C. A cross-talk between NFAT and NF- $x$ B pathways is crucial for nickelinduced COX-2 expression in Beas-2B cells. Curr Cancer Drug Targets. 2011;11(5):548-59, https://doi.org/10.2174/ 156800911795656001.

66. Zuo Z, Cai T, Li J, Zhang D, Yu Y, Huang C. Hexavalent chromium $\mathrm{Cr}(\mathrm{VI})$ up-regulates $\mathrm{COX}-2$ expression through an NF- $x$ B/c-Jun/AP-1-dependent pathway. Environ Health Perspect. 2012;120(4):547-53, https://doi.org/10.1289/ehp.1104179.

67. Bernard A, Roels H, Buchet JP, Lauwerys R. Decrease of serum Clara cell protein in smokers. Lancet. 1992;339(8809): 1620, https://doi.org/10.1016/0140-6736(92)91891-B.

68. Steerenberg PA, van Amelsvoort L, Lovik M, Hetland RB, Alberg T, Halatek T, et al. Relation between sources of particulate air pollution and biological effect parameters in samples from 4 European cities: An exploratory study. Inhal Toxicol. 2006;18(5):333-46, https://doi. org/10.1080/08958370500515913.

69. Bonner JC, Rice AB, Ingram JL, Moomaw CR, Nyska A, Bradbury A, et al. Susceptibility of cyclooxygenase-2-deficient mice to pulmonary fibrogenesis. Am J Pathol. 2002;161(2): 459-70, https://doi.org/10.1016/S0002-9440(10)64202-2.

70. Yoon JM, Lim JJ, Yoo CG, Lee CT, Bang YJ, Han SK, et al. Adenovirus-uteroglobin suppresses COX-2 expression via inhibition of NF- $x \mathrm{~B}$ activity in lung cancer cells. Lung Cancer. 2005;48(2):201-9, https://doi.org/10.1016/j.lungcan. 2004.11.005.

71. Sackmann-Sala L, Guidotti JE, Goffin V. Minireview: Prolactin regulation of adult stem cells. Mol Endocrinol. 2015;29(5):667-81, https://doi.org/10.1210/me.2015-1022.

72. Halatek T, Opalska B, Rydzynski K, Bernard A. Pulmonary response to methylcyclopentadienyl manganese tricarbonyl treatment in rats: Injury and repair evaluation. Histol Histopathol. 2006;21(11):1181-92, https://doi.org/10.14670/HH21.1181.

73. Yu-Lee LY. Prolactin modulation of immune and inflammatory responses. Recent Prog Horm Res. 2002;57:435-55, https://doi.org/10.1210/rp.57.1.435.

74. Lee SH, Nishino M, Mazumdar T, Garcia GE, Galfione M, Lee FL, et al. 16-kDa prolactin down-regulates inducible nitric oxide synthase expression through inhibition of the signal transducer and activator of transcription $1 /$ IFN regulatory factor-1 pathway. Cancer Res. 2005;65(17):7984-92, https://doi.org/10.1158/0008-5472.CAN-05-0631.

75. Nouhi Z, Chughtai N, Hartley S, Cocolakis E, Lebrun JJ, Ali S. Defining the role of prolactin as an invasion suppressor hormone in breast cancer cells. Cancer Res. 2006;66(3):1824-32, https://doi.org/10.1158/0008-5472. CAN-05-2292.

This work is available in Open Access model and licensed under a Creative Commons Attribution-NonCommercial 3.0 Poland License - http://creativecommons.org/ licenses/by-nc/3.0/pl/deed.en. 